\title{
Between Latin America and the Arab world: Rodrigo Rey Rosa and Alberto Ruy Sánchez in Morocco
}

In the 1980s, Guatemalan writer Rodrigo Rey Rosa traveled to Morocco where he attended Paul Bowles' creative writing workshop. La orilla africana (The African Shore, 1999), his novel set in Tangier about a Colombian tourist and a Moroccan, bisects and looks beyond the African and European shores. In 1975, Mexican writer Alberto Ruy Sánchez discovered Essaouira, a Moroccan city that evoked the Sonoran desert of his youth in northern Mexico, and produced a series of novels and a short story collection inspired by the ancient city of Mogador. These works trace several sets of cultural interactions: translations of the Orient in Latin American literature and Latin Americans in the Arab world. Focusing on these cultural encounters and trajectories, I examine some of the networks of literary and cultural exchange between Latin America and the Arab world and the models they offer to World Literature.

Latin American writers who have produced travel literature on North Africa include Domingo Sarmiento, Rubén Darío, Enrique Gómez Carrillo, Roberto Arlt, and Severo Sarduy ${ }^{1}$. In 1881, Cuban José Marti, writing for La Opinión Nacional in Caracas, commented on the anticolonial revolt in Egypt and expressed admiration for the struggle against British colonialism (Martí 2011: 113-117). Travel literature is not widely practiced in the Hispanic world, observes Rey Rosa (Esposito 2015). While Rey Rosa reinvents the travel genre in his novel set in Tangier, Ruy Sánchez has recreated Essaouira in his fiction. In 2000, Colombian writer Héctor Abad Faciolince traveled to Egypt where he spent two months and wrote a travelogue Oriente empieza in El Cairo (The Orient Begins in Cairo, 2002) as part of a cultural project $A \tilde{n} o$ O (2000), a collection of travel literature, commissioned by the Italian publisher Mondadori, and written by Latin American writers such

1 For Argentine Domingo Sarmiento's evocations of the Orient in Facundo o civilización y barbarie (Facundo: Civilization and Barbarism, 1845), see Spence (2007). For further commentary on the chronicles of Guatemalan Enrique Gómez Carrillo, notably De Marsella a Tokio: sensaciones de Egipto, la India, la China y el Japón (1906), and Nicaraguan Rubén Darío’s Cuentos y crónicas (1918), see Ortiz Wallner (2012). For Argentine Roberto Arlt's travels to Morocco in 1935, see Majstorovic (2006). Also, Cuban Severo Sarduy traveled to Morocco and Tunisia (Park 2010: 172).

Tahia Abdel Nasser, American University in Cairo

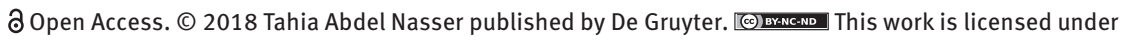
the Creative Commons Attribution-NonCommercial-NoDerivatives 4.0 License. 
as Roberto Bolaño and Rodrigo Rey Rosa about different cities at the start of the millennium ${ }^{2}$. The travelogue, a twenty-first century parody of the nineteenthcentury travel genre, offers a Latin American traveler's voyage en orient.

These Latin American novels offer South-South conceptions of the Orient and models of comparison in the periphery. Edward Said's foundational study Orientalism argues that European conceptions of the Orient are a form of domination based on inequality and asymmetry. For Said, Orientalism is "a Western style for dominating, restructuring, and having authority over the Orient” (1978: 3) based on European superiority and imperialism. Latin American Orientalism is largely different from European conceptions of the Orient based on the colonial encounter. Julia Kushigan notes that "Hispanic Orientalism" offers insight into the Hispanic world's long-standing "historical and intellectual contact with the Orient” beyond Western Europe’s domination (1991: 2). While Kushigan notes the cultural contact between the Orient and the Hispanic world, characterized by "a spirit of veneration and respect for the Orient unparalleled by other Western European nations" (1991: 3), most notably in works by Jorge Luis Borges, Octavio Paz, and Severo Sarduy, examples of Eurocentric Orientalism abound in Latin American cultural production. Hispanic Orientalism, Kushigan argues, opens up exchange with the Orient and uncovers an affinity between literatures that dates back to the Arabic sources of Spanish literature since the twelfth century (1991: 3). In Spanish America, literature evoked the mysticism of the Orient, a fascination with Oriental themes, and made comparisons between Latin America and the Arab world, specifically Argentines and Arabs (Kushigian 1991: 7-8). Argentine Orientalism, particularly the ways in which Arab and non-Arab Argentine writers employed the Orient and the Oriental to create a distinctly Argentine identity, Christina Civantos (2006) notes, offers insight into Latin America's heterogeneous culture. Likewise, Araceli Tinajero (2003) focuses on conceptions of the Far East in Latin American literature that reworks exoticism without imperial domination of the Orient.

Mary Louise Pratt's “contact zones” in Imperial Eyes may be adopted to study the encounters in novels by Rey Rosa and Ruy Sánchez where cultural contact is largely different from imperial encounters in "social spaces where disparate cultures meet, clash, and grapple with each other, often in highly asymmetrical relations of domination and subordination - such as colonialism and slavery" (Pratt 2008: 7). In these novels, Latin American travelers are far from nostalgic about the Oriental Other, but are rather familiar with Orientalist stereotypes and

2 Rey Rosa wrote El Tren A Travancore (Cartas Indias) (The Train to Travancore, 2002) about his trip to Chennai in 2000. 
willfully rework the Orient into Africa beyond the East or the West and an ancient mythical city that connects Latin America to North Africa. Ali Behdad's "belated Orientalism" is a late-nineteenth-century Orientalism based on desire and nostalgia as practices that enabled and perpetuated colonial power. Rather, these novels trace encounters that extend beyond exoticism to contact between Latin America and North Africa.

The travel of Latin American writers to the Arab world offers an Arab-Latin American model of World Literature that focuses on transatlantic exchange. Cultural encounters between Latin America and the Arab world have extended from a long history of Arab migration to Latin America, to Latin American Orientalism, the cultural production of the Arab diaspora in Latin America, and the circulation and translation of Latin American literature in the Arab world. Cultural interactions between Latin America and the Arab world have produced literature that traces new frameworks of South-South comparison. Today, the travel of Latin American writers to North Africa contributes further to these literary and cultural ties.

\section{The Tropics and Africa}

Rodrigo Rey Rosa (born in 1958) is one of the foremost writers of Guatemala, whose novels have been translated into English by American author Paul Bowles (1910-99), with a recent translation of The African Shore by Yale University Press. Born in Guatemala City, Rey Rosa settled occasionally in Tangier where he enjoyed the friendship of Bowles. In 1980, he enrolled in Bowles' creative writing workshop in Tangier and spent a year in Morocco (Guerrero 2002: 104; Gray 2007: 164). Though Rey Rosa is one of the better-known Central American writers in English, his connections to North Africa are understudied. Rey Rosa is the quintessential cosmopolitan writer whose travels from Guatemala to Morocco to India (and Spain and New York) offer new models of South-South comparison. His novels are infused with the Argentine experimentalism of Jorge Luis Borges in Central America (Esposito 2015), along with Guatemala's violence, all relocated to Morocco.

Rey Rosa reworks contact between Latin America and the Arab world through Third world encounters, in general, and his evocation of Tangier in his novels in particular ${ }^{3}$. The African Shore traverses the Atlantic and the Strait of Gibraltar, creating routes between Latin America and North Africa. Alexandra Ortiz Wallner

3 See the important study by Ottmar Ette and Friedericke Pannewick (2006). 
notes the reconfiguration of Latin American literature through the presence of the Arab world or the Orient in the Latin American tradition: The African Shore reconfigures Spanish American literature to interconnect with the Arab world, or in a broader sense, the Orient in the Spanish American literary tradition (2012: 247). In The African Shore, Rey Rosa, aware of the gulf that separates Latin America, the US, Europe, and North Africa (Dalmau 2005: 52), creates cultural and transnational encounters.

The African Shore is unique among Rey Rosa's novels for its focus on contact between Latin America and North Africa. The setting of Morocco, Rey Rosa writes, reworks and departs from Bowles’ Tangier: "by 1998 Morocco had become quite different, at least externally from the Morocco that Bowles had written about, or in a way invented. I guess I looked at Morocco, especially Tangier, as a territory that was his. [...] It's important to understand that I wrote this little novel in a state of happiness mixed with nostalgia" and as a "double farewell" to Bowles and Morocco (Esposito 2015). Some of Rey Rosa's novels feature Morocco: The African Shore (1999), his only novel set in Tangier and penned in the Hotel Atlas (Gray 2013: 144); El cojo bueno (The Good Cripple, 1996, translated into English in 2004), set in Guatemala and Morocco; and Severina, which includes a Moroccan bookseller. Though The African Shore is set in Tangier, Rey Rosa has maintained that where he writes does not matter to him (Gray 2007: 161). Rey Rosa, who lived in Tangier from 1982 to 1992 and spent summers in Tangier until 2001 (Goldman 2013: 74), writes about his recreation of Tangier in The African Shore:

I dared to write the book when I realized that the Tangier that Bowles had written about - or better yet, created - had changed so much that it was no longer the same city. [...] When I started writing the novella, I could sense that I would never live in Morocco again. The book became a sort of farewell. But I never thought of Tangier as a home. I've never been at peace at home - but in Tangier I often was. (Goldman 2013: 74)

The African Shore brings into focus contact between Guatemala and Morocco, or Latin America, Africa, and Europe, where tensions, difference, and the legacy of colonialism abound. Rey Rosa recounts:

It was winter and the heating in the Atlas never worked properly, so that when I was invited to spend the rest of my stay in a big $19^{\text {th }}$-century European house with large gardens in Monte Viejo, and with views of the cliffs that span both pillars of Hercules and the city of Tarifa set into the Spanish coast, I counted myself the luckiest Guatemalan in all Africa. (Gray 2013: 144)

His commentary brings to light the confluence of European, Arab, and African cultures in which a Guatemalan found himself, creating further Latin American ties to Africa. 
The African Shore tells the double story of a Colombian tourist stranded in Morocco when he loses his passport and an adolescent Moroccan shepherd, Hamsa, who wishes to migrate to Spain, seemingly separate but interconnected through an enigmatic owl. The Colombian tourist, unnamed for most of the novel, who now has an excuse not to return to Colombia, buys kif, purchases an owl from the market, and courts a young French archeology student, Julie, in Tangier. The Colombian tourist's encounters with Moroccans in Tangier are characterized by distance and otherness. The African Shore culminates in the Colombian tourist's passage to Spain and the flight of the owl from Hamsa beyond the African and European shores.

Rey Rosa weaves a relationship between Guatemala (Colombia in the novel) and Morocco, and thus explores contact and encounters in the periphery (García 2009: 22). Rey Rosa makes comparisons between Colombia and Morocco in The African Shore, but also writes with an awareness of the polarity between the Moroccan landscape, mostly desert, and Guatemala's "tropical exuberance" (Goldman 2013: 75). Though Rey Rosa has traveled to New York, Morocco, and India, Guatemala is present in his novels (Sánchez 2008). Guatemala casts a long shadow on Morocco, reproduced through the undercurrent of violence among Moroccans, Colombians, and Europeans in The African Shore. The theme of violence for Rey Rosa is perennial ${ }^{4}$. For example, The Good Cripple, a novel in which a Guatemalan is abducted for ransom and whose foot is amputated and sent to his father, begun at the Hotel Atlas in Tangier, Rey Rosa notes (Esposito 2015), was affected by reports of violence in Guatemala. Rey Rosa evokes the violence that characterizes "that border of all borders: the strait that separates Africa and Europe where they touch the Atlantic", as described in the English translation the Strait of Gibraltar in which Africans perish as they attempt to cross into Europe. A restrained violence - or what he calls "interior violence" (Posadas 2005) - seeps into the novel, most notably in Hamsa's final proposition to Julie in exchange for the owl and the encounter between the Colombian tourist and his assailant in Spain. Throughout the novel, juxtapositions and comparisons between drugs, crime, and violence in Morocco and in Colombia abound: the Colombian concedes to a Moroccan cab driver that Colombia is "More or less like here" 5 or "Horrible, in other words" (Rey Rosa 2013: 88) ${ }^{6}$.

The city of Tangier revives conceptions of the East: Tangier is exotic, decadent, and enigmatic (Awaad 2015: 121). In The African Shore, Tangier is characterized

4 On the theme of violence in Rey Rosa's literature, see Goldman (2013).

5 "Más o menos como aquî" (Rey Rosa 2010: 107).

6 "Horrible, entonces” (Rey Rosa 2010: 107). 
by corruption, smuggling, prostitution, repression, and shantytowns. The topography and culture of Tangier evoke cultural syncretism and its colonial legacy: the city is home to Europeans, Muslims, provincial Moroccans, Africans (who come there to cross the isthmus), and the Colombian. Tangerines are "polyglots", Rey Rosa notes (Esposito 2015), whose languages evoke an ethnically and culturally mixed heritage. Moreover, the city sets the stage for further encounters and tensions between Europeans, Moroccans, and Colombians. Scenes evoke stereotypes of poverty: "Several begging children circled among the tourists, kissing their hands, their sleeves and the folds of their shirts" (Rey Rosa 2013: 58) ${ }^{7}$. In one of her faxes, the Colombian's wife reports what his uncle thinks of Tangier: "He says everyone knows it's one of the sin capitals of the world" (Rey Rosa 2013: 111) ${ }^{8}$. Tangier, a labyrinthine Mediterranean city, looks "Asian" (Rey Rosa 2013: 43), replete with European stores and American food chains. It is not only the locus of Arab, Portuguese, French, and Spanish influences but also where the Latin American traveler is distanced from the familiar (Ortiz Wallner 2012: 246).

The African Shore captures Moroccan-Colombian interactions, allowing us insight into how Colombians and Moroccans read (or misread) each other in the periphery. While Rey Rosa offers the Colombian tourist's conceptions of Morocco and Moroccans, he also offers Moroccans' perceptions of foreigners. For Hamsa, foreigners are the Other, seen within the European-Islamic encounter. The way that Hamsa sees the Colombian tourist at the French Madame Choiseul's house evokes resemblance and difference between the Colombian and Moroccans: "Now a man, who could have been Moroccan but who, judging by his clothes and way of walking, must have been European” (Rey Rosa 2013: 17) ${ }^{9}$. Likewise, a local cab driver mistakes the Colombian for a Moroccan, Tunisian or Egyptian. Though he may pass for a local, his status of foreigner likens him to the colonial European in an example of the periphery seen from the periphery, but through the hegemony of the West (García 2009: 36). The guide Rashid holds stereotypes of the tourist and exploits him, conflating Colombians with Europeans. This is confirmed by the "tourist-traveler" ("el turista-viajero"), who recalls the travelers to the Orient and moves seamlessly between the European community of Tangier and the Medina (Awaad 2015: 125) - the European residences in Monte Viejo, Sidi Mesmudi, and the environs of Tangier. Attracted to Tangier, drawn to sensuality

7 "mientras varios niños pordioseros revoloteaban entre ellos, y besaban sus manos o las mangas o faldas de sus camisas” (Rey Rosa 2010: 75).

8 "Dice que todo el mundo sabe que es una de las capitales de la perdición” (Rey Rosa 2010: 131).

9 "Ahora un hombre, que podia ser un magrebí pero que, a juzgar por la ropa y el andar, debía de ser un europeo" (Rey Rosa 2010: 27). 
and drugs but distant from the culture, the Colombian tourist maintains the pose of foreigner or cosmopolitan in a magical city. The Colombian's contact with Moroccans is characterized by otherness: "In front of him, Moroccan heads passed by, then seemed to multiply. [...] Eyes that reminded him of other eyes, but in different faces" (Rey Rosa 2013: 34-35) ${ }^{10}$. The Colombian does not attempt to read the Other, but "heads" and "eyes" are a synecdoche for Moroccans. His contact with Hamsa is cursory and he fails to read the young Moroccan's interest in the owl. By the novel's end, he accepts the Moroccan guide Rashid's proposition to cash betting cards in Mellila for a commission and, with a new passport, crosses the Strait of Gibraltar into Spain but instead purchases a ticket to Malaga to slip further into the Peninsula. At that moment, he encounters his double, a Moroccan who says his name is Ángel Tejedor (literally, weaver), the Colombian's own name, and accosts him for his passport and the ticket. All encounters converge on the moment in which the Colombian tourist, whose anonymity has hitherto been preserved, encounters Rashid's partner who has followed him to Spain. The encounter epitomizes mutual distrust, an "elemental struggle", and the instinct "that he [his assailant] had to kill him if he was going to become him [the Colombian]" (Rey Rosa 2013: 125) ${ }^{11}$. The encounter uncovers the name of the Colombian and sets the Moroccan as his “other" (García 2009: 31) and his double. Ottmar Ette notes the triangulation of Colombia-Morocco-France in the novel and its implications for literature in general:

Africa, Europe, and America, or accordingly, Morocco, France, and Colombia, are so interwoven with one another that the transcontinental and transnational dimension in Moroccan Tangier creates a translocal microcosm, so to speak, upon which is superimposed, in a concentrated form, the long history of Spanish and Portuguese, English and French colonialism. (2016: 47)

Rey Rosa is "intimately familiar" with the locales of The African Shore, the transnational Central American novel, and the translation between languages and cultures in the "insular world of Tangier" (Ette 2016: 47-48). The encounters that unfold in Tangier and the Central American novel further enmesh cultures and languages, creating a model of transnational literature and Arab-Latin American literary ties.

The African Shore centers on the enigma and exchange of an owl - mystical, magical, but also sinister - that characterizes these Colombian-Moroccan cultural

10 "Frente a él, las cabezas marroquíes pasaban por la plaza y parecían multiplicarse. [...] Ojos que recordaban otros ojos, pero en caras diferentes” (Rey Rosa 2010: 49).

11 "que el otro neceitaba matarlo para convertirse efectivamente en él” (Rey Rosa 2010: 145). 
encounters. Paul Bowles described Rey Rosa in his creative writing workshop thus: "a Guatemalan, who wrote in Spanish" and invented "situations which were generally sinister" (Gray 2013: 140). The owl brings together the characters and intersects the plotlines through interactions that converge upon its possession. It stands for a complex system of exchange, sale, purchase, and resale where the forms of transfer are subject to mistranslation across cultures (García 2009: 41) and offers a set of cultural referents - superstition, bad luck, magic, and ancient knowledge. Purchased by the Colombian and stolen by the Moroccan, a possession that is important to the tourist and an obsession of Hamsa who wishes to create an amulet made from an owl's eye to fight off sleep and help the smugglers, the owl sees both. In the section "The Owl's Eyes", the owl inspects the Colombian with curiosity. The owl splits and brings Ángel and Hamsa together. In the end, the novel refocuses attention on the owl, "coveted by both sides Christian and Muslim" and "through whose eyes and ears we sometimes see and hear the world, both sides of it", the translator Jeffrey Gray notes (2013: 143). The novel ends with the owl's flight over the cliff overlooking the Strait of Gibraltar, "between cultures and continents", and circling beyond African and European shores (Gray 2013: 146).

The novel's title refers to "the African bank" or "the African side" of the Strait of Gibraltar rather than the European shore, or Spain (Gray 2013: 142). It focuses on the East, on Africa in Latin American-African encounters, and contact in the periphery. The African shore is not only the European shore in Africa but also the border of the Islamic world in Africa and thus can be interpreted as another bank for Central America (Ortiz Wallner 2012: 254). Ortiz Wallner, describing Rey Rosa as "the most universal and cosmopolitan of contemporary Guatemalan writers", notes "the presence of diverse settings serves to relativize borders, be these national, regional, or continental” (2013: 137). The African Shore circumvents borders and renews contact among European, African, Arab, and Latin American cultures in North Africa and Central American literature.

\section{Mexico and Mogador}

Alberto Ruy Sánchez (born in 1951) - Mexican novelist, critic, and editor of the prestigious Latin American arts magazine Artes de México - has set his novels in Morocco and reworked Arab culture in Spanish. When he undertook a trip to Morocco in 1975, he discovered Mogador, the ancient name for the Moroccan city of Essaouira on the Atlantic coast that would inspire his trilogy - Los nombres del aire (Mogador: The Names of the Air, 1987), Los jardines secretos de Mogador (The Secret Gardens of Mogador, 2001), and En los labios del agua (On the Lips 
of the Water, 1996) ${ }^{12}$. En los labios del agua features a Mexican of Arab origin - a heritage that Ruy Sánchez reworks in his novels.

Mogador, a Moroccan port on the Atlantic coast and an entrance to the Sahara Desert, renamed Essaouira in 1953, is characterized by a mixed culture - Jewish, Muslim, Berber, and Arab (Ruy Sánchez 2006: 261). The city is an emblem of multiculturalism and cultural syncretism. Like the centrality of Tangier in The African Shore, Mogador in Ruy Sánchez's novels is a port that links South and North Africa with Europe (Ruy Sánchez 2006: 261) and a city that connects Morocco to Mexico or North Africa to Latin America. Attracted to Morocco, Ruy Sánchez writes:

\begin{abstract}
But why does a Mexican feel compelled to write about Morocco? [...] What Morocco gave me is much more than an interesting location for my stories, as some people tend to believe. And certainly not a northern fascination for the exotic south, described by Edward Said as Orientalism. I come from another south, and that changes everything, allowing me to develop the theory of a possible south-south relationship which I ironically term "Horizontal Orientalism”. (Ruy Sánchez 2006: 261-262)
\end{abstract}

On his first journey to Mogador Ruy Sánchez relates that he was shocked to discover that it was so distant from Mexico yet so profoundly familiar; it seemed to be "another Mexico" (2006: 262). Moroccans, too, felt the same when they arrived in Mexico, a sentiment which he attributes to a shared legacy: "Our legacy derives from five centuries of mixing Indian and Spanish blood, but we must not overlook the Arabic heritage running through our veins, introduced by the Spaniards” (Ruy Sánchez 2006: 262). Ruy Sánchez traces this legacy to Arab influence in Andalusian Spain and suggests that Mexicans are descended from Berbers in North Africa and Moorish ancestry through contact with Spain a heritage that can be found in his Mexican mestizaje (2006: 264). Arabic in the Spanish language and Arab culture traveled to America through language, mestizaje, and craftsmanship (pottery and textiles), and, for him, Morocco and Mexico descend from Andalusian Spain (2006: 266). His discovery of Morocco through "the walled city of Essaouria-Mogador" (2006: 268) uncovered parallels with Mexico, that Morocco and Mexico share a common cultural heritage and that literature expresses that continuity (Benlabah 2004).

Mexico and Morocco are intimately intertwined in Ruy Sánchez's evocation of Arab characters in a Moroccan setting. Ruy Sánchez traces this interconnection to the cultural and historical proximity of Mexico and Morocco, connected by al-Andalus. He notes: "In Morocco, I discovered a cultural territory that borders

12 Mogador: The Names of the Air was translated into Arabic by Fatiha Benlabá and published in Essaouira by Editorial Aliseos (Lahrech 1998). 
on my own; an alternate Mexico separated by many seas” (Ruy Sánchez 2000: 68). For him, Mexico and Morocco are descended from Arabic Andalusia and he maintains that there is no exoticism (Ruy Sánchez 2000: 65). Like Rey Rosa, implicit in his endeavor is that literature has no borders. Moreover, he focuses on a shared culture beyond Europe and a form of Orientalism "that is not only clearly horizontal but that flows in two directions” (Ruy Sánchez 2000: 69). As he notes, "If the word Maghreb means 'west,' and Morocco thus constitutes the Far West of the East, then Mexico is also the Far West of its own continent" (Ruy Sánchez 2000: 69). He suggests that Mexicans are descended from Arabic Andalusian immigrants to America instead of Spanish and indigenous Mexicans, a connection that has consequences for his literature and the model it creates that of Arab and Latin American interconnections.

The novels of Ruy Sánchez evoke Arab-Islamic culture, reworked in Latin American literature and a product of the discovery of the East on his trip to Morocco, as well as the affinities between Andalusian literature, culture, and the landscape of Mexico and Morocco. These affinities are framed in the notion of "horizontal Orientalism" which calls for South-South exchange through Mexico (Lahrech 1998).

Mogador: The Names of the Air (henceforth Mogador) focuses on an Arab woman, Fatma, and her discovery of desire. Set in the ancient city of Mogador, Mogador recounts the story of Fatma, a young Moroccan woman so profoundly possessed by desire she looks continually toward the sea. Along with her desire, her melancholy and solitude grow, as though she is possessed so that when people speak of her, “they wouldn't say 'there she is,' but rather, 'it seems as if she's there"” (Ruy Sánchez 1992: 30)13. The blurb describes the Arab Latin American interactions in the novel thus: a "fusion of Latin American magical realism with Arabic geometric and mystical imagery”. Evocations of Fatma's sexual awakening intimately capture her sensuality in a manner that evokes the cultural atmosphere of Essaouira and the forms of Latin American literature whereby characters and events are both mundane and magical. Mogador is both Orientalist in its evocations of an Arab woman's desire and extends beyond Latin American Orientalism towards an interconnected Mexican and Moroccan heritage.

Mogador is a magical or fictional city but also a real one. The marvelous city of Mogador uncovers the Muslim roots of Ruy Sánchez's heritage (Lahrech 1998). Arab-Islamic origins can be traced back to the Spanish colonization of Mexico, to conquistadors in America from al-Andalus in the Iberian Peninsula, among whom were pseudo-conversos of Muslim or Jewish origin who fled Spain and

13 “no decían ‘allá está', sino ‘allá parece que está”” (Ruy Sánchez 1996: 41). 
came with Columbus to the New World (Lahrech 1998). Ruy Sánchez invokes an Arab-Muslim heritage and Arab migration to Latin America - cultural ties that are elaborated by such writers as Jorge Luis Borges, Jorge Amado, and Gabriel García Márquez. For Ruy Sánchez, Mexico inherited the ethnic and cultural mixing that characterized al-Andalus. Mogador evokes his youth in the Sonora desert and Morocco offered him an understanding of Mexican culture and his mestizaje (Ruy Sánchez 2006: 272). Like Tangier in Rey Rosa’s novel, Mogador connects both sides of the Atlantic. Ruy Sánchez evokes the city of Mogador, the port, and public bath (hammam) in the novel. The walled city-port of Mogador is described as a labyrinth of markets and bathhouses:

[T] he principal street, The Way or Street of the Snail, which leads by twists and turns from the walls that surround the island to the central plaza, home to the public baths and to the three temples of the three religions that cohabit the port city. To the people of Mogador, the city was an image of the world: a map of the external, as well as the spiritual, life of men. (Ruy Sánchez 1992: 5-6) ${ }^{14}$

Ruy Sánchez's evocations of Mogador and Fatma's desire intimately rework medieval Arabic literature by Tunisian Muhammad al-Nafzawi (The Perfumed Garden of Sensual Delight), Persian philosopher, theologian, and reformer Abu Hamid Muhammad al-Ghazali, the Sufi mystic Ibn Arabi, and Cordoban theologian Ibn Hazm (Lahrech 1998). Ruy Sánchez's discovery of classical Arabic literature is central to the themes of Mogador. Mogador was inspired by Andalusian poet, scholar, and theologian Ibn Hazm's masterwork Tawq al-hamāmah (The Ring of the Dove: A Treatise on the Art and Practice of Arab Love), a love treatise that inspired Ruy Sánchez's exploration of the language of love, the gaze, and the intensity of desire (Lahrech 1998). In Mogador, a young scholar of the Koran is besotted with Fatma and possessed by her in his repose, reading, and prayer. The young man, “a Saracen at heart” (Ruy Sánchez 1992: 18) ${ }^{15}$, looks through the Koran for ways to interpret signs in Fatma's behavior. One day he enters the library and opens the case of "forbidden books":

He had already heard mention of the treatise on love and lovers by Ibn Hazm, and holding it in his hands, he went straight to the chapter on The signs of love made with the eyes. "The eyes often play the role of messengers and thus convey what is desired. If the other

14 "la calle principal, La Vía o calle Del Caracol, que dando giros lleva de las murallas que rodean toda la isla a la plaza central, donde están los baños públicos y los tres templos de las religions que conviven en ese Puerto. La ciudad, para la gente de Mogador, era imagen del mundo: un mapa de la vida tanto externa como spiritual de los hombres” (Ruy Sánchez 1996: 17-18).

15 “sarraceno de corazón” (Ruy Sánchez 1996: 30). 
four senses are doors that lead to the heart and windows that open onto the soul, sight is, of all the senses, the most subtle and offers the most effective results. The gaze repels and attracts, promises and threatens, reprimands and offers encouragement, commands and forbids. (Ruy Sánchez 1992: 18-19) ${ }^{16}$

The young scholar senses that Ibn Hazm's treatise holds the key to the gazes Fatma directs at him. In The Ring of the Dove, Ibn Hazm observes the signs of love of which the first is the gaze, parses the variety of the lover's gaze, and remarks upon his unflinching gaze, his affectation of disinterest, his rapt attention, his desire to be in the beloved's company, the confusion and excitement upon the beloved's sudden appearance, or agitation on beholding someone who resembles his beloved or on hearing his beloved's name. Instead, the narrator comments on the signs of Fatma's desire - that they could have formed a poetic inventory of the signs of desire, as Ibn Hazm has interpreted the signs of love. The scholar, while reading these prohibited books, "would discover a deeply-rooted tradition in Arabic-Andalusian literature, the tradition of the adab [literature], the treatise that is at once a narrative and a poem, usually based in large part on the personal experience of the author" (Ruy Sánchez 1992: 20-21; emphasis in original) ${ }^{17}$. Likewise, Ruy Sánchez draws upon the Sufi mystic Ibn Arabi in "the nine fundamental steps" Fatma takes to master the silence of the nine senses and thus open herself to the world (Ruy Sanchez 1992: 55).

The evocation of love and desire in magical and ancient Mogador, enclosed and exotic, creates an exoticism that characterizes Orientalist literature, especially through the male and foreign gaze directed at women in general and Fatma in particular not only within the prohibited space of women but also of the intimate quarters of the public baths. Ruy Sánchez creates Mogador, "the imaginary city of desire", in his novels. The narrator (and foreign male author) intimately describes the ritual of the hammam and women's sexual initiation, dreams, and desires. Ruy Sánchez employs the complex geometry of Morocco's architecture to create a structure that evokes desire: "With their marvelous architecture of the

16 "Ya había oído hablar del tratado sobre el amor y los amantes de Ibn Hazm, y cuando lo tuvo en las manos fue directamente hacia el capítulo sobre Las señas del amor hechas con los ojos. 'Los ojos hacen a menudo las veces de mensajeros y con ellos se da a entender lo que se quiere. Si los otros cuatro sentidos son puertas que conducen al corazón y son ventanas hacia el alma, la vista es entre todos el más sutil y el de más eficaces resultados. Con la mirada se aleja y se atrae, se promete y se amenaza, se reprende y se da aliento, se ordena y se veda" (Ruy Sánchez 1996: 30).

17 "descubría una tradición muy arraigada en la literatura arabigoandaluza, la tradición del $a d a b$ : del tratado que es a la vez una narración y un poema, generalmente vividos, en gran parte, por el autor” (Ruy Sánchez 1996: 32). 
initiation into desire, the Arabic public baths, the Hammam, become a symbol for Fatma's own initiation in Los nombres del aire" (Ruy Sánchez 2000: 71; emphasis in original). The narrator violates the sanctity of the public bath frequented by the women of Mogador and Fatma where she encounters Kadiya, a mysterious woman: "What is illicit outside is, inside the Hammam, as unsubstantial as a fruit whose peel dissolves in the air" (Ruy Sánchez 1992: 38) ${ }^{18}$. He enters "the forbidden rooms of the Hammam” (Ruy Sánchez 1992: 56) ${ }^{19}$ to describe the women's desires. In the section "The Names", the narrator evokes the forbidden and interrupted desires of the inhabitants of Mogador: the melancholy and sensual Fatma who encounters Kadiya in the public baths; Amjrus, the corpulent auctioneer in the fish market whose encounters in a floating brothel and attraction to Fatma express ample desire; Mohammed, a fisherman who courts Fatma and attempts to interpret her gestures and melancholy gaze, instructed by Amjrus into the art of transactions in the fish market, and unaware of the prospect of an illicit transaction; Kadiya, a woman of "nocturnal transactions” (Ruy Sánchez 1992: 89), desired by Fatma, who eludes her. Mexican and Arab-Muslim motifs are interwoven in the novel, creating an interconnection between Mexico and Morocco. These include the magical evocations of desire along with the geometric architecture of the public bath that further inspires that desire.

\section{Arab-Latin American models}

Together, Rey Rosa's The African Shore and Ruy Sánchez's Mogador set out to circumvent and rework Orientalist stereotypes respectively. These novels further contact and exchange between Latin America and the Arab world or North Africa. In The African Shore, center and periphery converge in the owl (García 2009: 42) who circles beyond Africa and Europe. In Mogador, Ruy Sánchez's evocation of Fatma's desire and sensuality reworks Orientalism through the interconnection of Mexico and Morocco. While the violence of Rey Rosa's novels permeates encounters between cultures in The African Shore, desire seeps into Ruy Sánchez's evocation of Morocco.

As Rey Rosa brings into focus misunderstandings and misconceptions between Latin America and North Africa, Ruy Sánchez reworks Orientalism to

18 "Lo que afuera es ilícito, dentro del hammam es tan inconsistente como una fruta cuya cáscara se diluye en el aire” (Ruy Sánchez 1996: 49).

19 "las salas prohibidas del hammam” (Ruy Sánchez 1996: 68). 
create a shared heritage between Mexico and Morocco. Rey Rosa and Ruy Sánchez offer a trajectory of Latin American writers who have traveled to Morocco and recreate contact between Latin America and North Africa. Rey Rosa looks beyond the dichotomies structuring his novel. On the other hand, Ruy Sánchez's seemingly Orientalist evocations of an Arab woman in an exotic city and adaptation of Arabic literature serve to intertwine cultures. Both writers bring to light SouthSouth connections and horizontal Orientalism in forms that are instead ways to examine cultural exchange and contact. Indeed, they contribute to a model of Arab and Latin American interconnections in the semi-periphery. More recently, Rey Rosa has extended these connections to the East further in Fábula asiática ("An Asian Fable", 2016) where a Mexican writer travels to Tangier and is drawn into the story of a Moroccan boy that takes him from Tangier to Istanbul and thus creates further routes between Latin America and the Middle East ${ }^{20}$.

Rey Rosa and Ruy Sánchez's travel literature offers a model of comparison that focuses on cultural exchange between Latin America and the Arab world and calls for further practices of World Literature that bring Latin American and Arabic literature into contact. They elaborate a model beyond exoticism toward cultural contact and exchange: Rey Rosa brings to light the triangulation of Latin America, Europe, and North Africa, and Ruy Sánchez creates further ties between Latin America and North Africa through transatlantic routes between Mexico and Morocco.

\section{Works cited}

Abad Faciolince, Héctor (2002): Oriente empieza en El Cairo. Bogotá: Alfaguara.

Behdad, Ali (1994): Belated Travelers: Orientalism in the Age of Colonial Dissolution. Durham: Duke University Press.

Awaad, Hala Abdelsalam (2015): "La orilla africana y la búsqueda de identidad". In: Achiri, Noureddine/Baraibar, Álvaro and Schmelzer, Felix K. E. (eds.): Actas del III Congreso IberoAfricano de Hispanistas. Pamplona: Biblioteca Áurea Digital, pp. 121-137.

Banlabah, Fatiha (2004): “Alberto Ruy Sánchez ou le Voyage de Retour”. In: <http://www. angelfire.com/ar2/libros/FATIHA.html> (last visit: 05/30/2017).

Bolaño, Roberto (2011): Between Parentheses. Transl. by Natasha Wimmer. New York: New Directions.

Civantos, Christina (2006): Between Argentines and Arabs: Argentine Orientalism, Arab Immigrants, and the Writing of Identity. Albany: State University of New York Press.

20 I am indebted to Alexandra Ortiz Wallner for this insight. 
Dalmau, Miguel (2000): “Engimas y transparencias”. In: Revista de libros de la Fundación Caja Madrid, 43-44, p. 52.

De la Torre, Roberto (2011): Review of The Secret Gardens of Mogador: Voices of the Earth by Alberto Ruy-Sánchez and Rhonda Dahl Buchanan. In: Chasqui, 40, 1, pp. 219-220.

Durante, Erica (2007): ‘Empiezo a escribir escribiendo’. Un arsenal de escritura: Rodrigo Rey Rosa entre Borges y Bioy”. In: Revue Recto/Verso, 2, pp. 1-8.

Esposito, Scott (2015): “Interview with Rodrigo Rey Rosa”. In: The White Review. <http://www. thewhitereview.org/interviews/interview-with-rodrigo-rey-rosa/> (last visit: 2/20/2017).

Ette, Ottmar (2016): Transarea: A Literary History of Globalization. Transl. by Mark W. Person. Berlin: de Gruyter.

Ette, Ottmar/Pannewick, Friederike (eds.) (2006): ArabAmericas: Literary Entanglements of the American Hemisphere and the Arab World. Madrid/Frankfurt am Main: Iberoamericana/ Vervuert.

Flores, Ronald (2008): “The Enigmatic Drifter”. In: The Latin American Review of Books. <http:// www.latamrob.com/archives/64> (last visit: 2/25/2017).

García, Claudia (2009): “Territorialidad fantasmática y periferias: una lectura de La Orilla Africana, de Rodrigo Rey Rosa”. In: A Contracorriente: Una revista de historia social y literatura de América Latina (A Journal on Social History and Literature in Latin America), 6, 2, pp. 21-45.

Goldman, Francisco (2013): “Rodrigo Rey Rosa”. Transl. by Ellie Robins. In: Bomb, 125, pp. 70-76.

Gray, Jeffrey (2007): “Placing the Placeless: A Conversation with Rodrigo Rey Rosa”. In: A Contracorriente: Una revista de historia social y literatura de América Latina (A Journal on Social History and Literature in Latin America), 4, no. 2, pp. 160-186.

- (2013): “Afterword: Rodrigo Rey Rosa and Tangier”. In: Rey Rosa, Rodrigo (2013): The African Shore. Transl. by Jeffrey Gray. New Haven: Yale University Press, pp. 139-146.

Guerrero, Gustavo (2002): “Conversación con Rodrigo Rey Rosa”. In: Cuadernos hispanoamericanos, 624, pp. 103-108.

Ibn Ḥazm, 'Alī ibn Aḥmad (2004): Ṭawq al-ḥamāmah fĩ al-ulfah wa-al-ullāf. Beirut: Dār al-Jīl lil-Nashr wa-al-Ṭibā'ah wa-al-Tawzī‘.

- (1953): The Ring of the Dove. London: Luzac \& Co.

Kushigian, Julia A. (1991): Orientalism in the Hispanic Literary Tradition: In Dialogue with Borges, Paz, and Sarduy. New Mexico: University of New Mexico Press.

Lahrech, Oumama Aouad (1998): “Alberto Ruy Sánchez y Mogador: Puente colgante entre las dos orillas del Atlántico”. In: 〈http://www.angelfire.com/ar2/libros/Oumamogador.html〉 (last visit: 5/30/2017).

Majstorovic, Gorica (2006): "From Argentina to Spain to North Africa: Travel and Translation in Roberto Arlt”. In: Iberoamericana, 6, 21, pp. 109-114.

Martí, José (2011): Obras completas. Volumen 14. La Habana: Editorial de Ciencias Sociales. Luzárraga, Raquel (2005a): “Entrevista a Rodrigo Rey Rosa”. In: Maga. Revista Panameña de Cultura, 57-58, pp. 109-114. 〈http://www.utp.ac.pa/secciones/pdf/Maga_57_58.pdf> (last visit: 6/1/2017).

Luzárraga, Raquel (2005): “Reseña: Rodrigo Rey Rosa. La orilla Africana”. In: Maga. Revista Panameña de Cultura, 57-58, pp. 108-109. <http://www.utp.ac.pa/secciones/pdf/ Maga_57_58.pdf> (last visit: 6/1/2017).

Ortiz Wallner, Alexandra (2013): “Rodrigo Rey Rosa (Guatemala, 1958)”. In: Corral, Will H./De Castro, Juan E. and Birns, Nicholas (eds.): The Contemporary Spanish-American Novel: Bolaño and After. New York: Bloomsbury, pp. 136-141. 
- (2012): El arte de ficcionar: la novela contemporánea en Centroamérica. Madrid/ Frankfurt am Main: Iberoamericana /Vervuert.

Park, Paula (2010): “Staging Absence: Severo Sarduy's Fictive Orientalism in From Cuba with a Song”. In: López-Calvo, Ignacio (ed.) (2010): One World Periphery Reads the Other: Knowing the "Oriental" in the Americas and the Iberian Peninsula. Newcastle: Cambridge Scholars Publishing, pp. 172-187.

Posadas, Claudia (2005): “Una escritura sin precipitaciones. Entrevista con Rodrigo Rey Rosa”. In: Espéculo. Revista de Estudios Literarios, 29 <http://www.ucm.es/info/especulo/ numero29/reyrosa.html> (last visit: 1/6/2017).

Pratt, Mary Louise (2008): Imperial Eyes: Travel Writing and Transculturation. London: Routledge.

Rey Rosa, Rodrigo (2016): Tres novelas exóticas. Mexico City: Alfaguara.

- (2016): Fábula asiática. Mexico City: Alfaguara.

- (2013): The African Shore. Transl. by Jeffrey Gray. New Haven: Yale University Press.

- (2010): La orilla africana. 2nd ed. Guatemala City: F \& G Editores.

Ruy Sánchez, Alberto (2006): “The Nine Gifts that Morocco Gave Me”. In: Ette, Ottmar/ Pannewick, Friederike (eds.): ArabAmericas: Literary Entanglements of the American Hemisphere and the Arab World. Frankfurt am Main/Madrid: Vervuert/Iberoamericana, pp. 261-273.

- (2000): “Writing on the Body’s Frontiers". Transl. by Michelle Suderman. In: Studies in the Literary Imagination, 33.1, pp. 65-72.

- (1996): Los nombres del aire. México: Alfaguara.

- (1992): Mogador: The Names of the Air. Transl. by Mark Schafer. San Francisco: City Lights Books.

Said, Edward (1978): Orientalism. New York: Pantheon.

Sánchez, Escarlata (2008): “Entrevista con Rodrigo Rey Rosa y Alan Mills” In: Puente de las Artes <http://www.rfi.fr/actues/articles/108/article_9999.asp> (last visit: 06/01/2017).

Spence, Julie King (2007): “Of Bedouins and Gauchos: Orientalism in Argentina”. In: López-Calvo, Ignacio (ed.): Alternative Orientalisms in Latin America and Beyond. Newcastle: Cambridge Scholars Publishing, pp. 182-191.

Tinajero, Araceli (2003): Orientalismo en el modernismo hispanoamericano. West Lafayette: Purdue University Press. 